\title{
Application of Wireless Power Transmission Led Lighting System in Propagation of Chrysanthemum and STRaWberRY ${ }^{1}$
}

\author{
Aplicação de Sistema de Transmissão de Energia de Iluminação Led Sem Fio em Propagação de \\ Crisântemo e Morango
}

NAM, N.B. ${ }^{2}$, HUY, N.P. ${ }^{2}$, LUAN, V.Q. ${ }^{2}$, TUNG, H.T. ${ }^{3}$, and NHUT, D.T. ${ }^{2}$

\begin{abstract}
Wireless power transmission has been recently used to charge batteries in portable devices. This is the first study to combine this technology with light-emitting diodes (WPT-LP) for plant tissue culture application. We also present the comparison of the in vitro growth of chrysanthemum and strawberry plantlets under the new LED lighting system; LED - Uni-Pack (LP) system; LED tube and fluorescent light (FL). The results showed that fresh weight $(1.42 \mathrm{~g})$, dry weight $(118.67 \mathrm{mg})$, plant height $(5.68 \mathrm{~cm})$, leaf area $\left(3.59 \mathrm{~cm}^{2}\right)$ and chlorophyll content $\left(47.9 \mu \mathrm{g} \mathrm{g}^{-1}\right)$ of chrysanthemum plantlets under the WPT-LP system were higher than those under FL and LED tube. Similar results were also recorded on the strawberry plantlets. Our results suggested that utilizing WPT-LP system saves the culture space considerably compared with the conventional downward lighting system with fluorescent lamps. The results also indicated that the subsequent growth and development of chrysanthemum and strawberry plantlets derived from WPT-LP system were either equal to or better than those from LP system under LED tube or FL.
\end{abstract}

Keywords: chrysanthemum, development, growth, LEDs, photosynthetic photon flux density, wireless power transfer.

\begin{abstract}
RESUMO - A transmissão de energia sem fio tem sido usada recentemente para carregar baterias em dispositivos portáteis. Este estudo é o primeiro a combinar essa tecnologia com diodos emissores de luz (WPT-LP) para aplicação em cultura de tecido vegetal. Também são apresentadas comparações entre crescimento in vitro de plântulas de crisântemo e morango com o novo sistema de iluminação: sistema LED - Uni-Pack (LP), tubo LED e luz fluorescente (FL). Os resultados demonstraram que peso fresco (1,42 $\mathrm{g})$, peso seco $(118,67 \mathrm{mg})$, altura da planta $(5,68 \mathrm{~cm})$, área foliar $\left(3,59 \mathrm{~cm}^{2}\right) \mathrm{e}$ conteúdo de clorofila $\left(47,9 \mu \mathrm{g} \mathrm{g}^{-1}\right)$ de plântulas de crisântemo submetidas ao sistema WPT-LP foram maiores do que os daquelas submetidas a FL e tubo LED. Resultados similares também foram registrados em plântulas de morango. Esses resultados sugerem que, usando-se o sistema WPTLP, tem-se uma economia de espaço de cultura considerável em comparação ao sistema convencional de iluminação descendente com lâmpadas fluorescentes. Os resultados também indicaram que o crescimento subsequente ao desenvolvimento de plântulas de crisântemo e morango provenientes do sistema WPT-LP foi igual e/ ou melhor que o daquelas oriundas dos sistemas LP e tubo LED ou FL.
\end{abstract}

Palavras-chave: crisântemo, desenvolvimento, crescimento, LEDs, densidade de fluxo de fótons fotossintético, transferência de energia sem fio.

\section{INTRODUCTION}

Light is one of the most important factors in the regulation of plant growth and development. Green plants, which convert light energy into chemical energy via the process of photosynthesis, use light as a source of information for photoperiodism (night/day length), phototropism (light direction), and photomorphogenesis (light

Recebido para publicação em2.2.2015 e aprovado em 6.6.2016.

2 Tay Nguyen Institute for Scientific Research, Vietnam Academy of Science and Technology, Dalat city, Lam Dong province, Vietnam, <nguyenbanam1985@gmail.com>; ${ }^{3}$ Universidade Hue de Ciências Hue City, na província de Thua Thien Hue, Vietnam. 
quantity and quality). These responses depend on the photosynthetic photon flux density (PPFD), light quality, duration and photoperiod (Taiz and Zeiger, 2002). Therefore, plant growth could be controlled by artificial light in the greenhouse and in vitro.

Fluorescent lamps have been the main light source commonly used for in vitro tissue culture. In the past few years, light emitting diodes (LEDs) have arisen as an alternative light source for plant tissue culture. Compared to conventional fluorescent lamps, LEDs have improved features, including smaller mass and volume, longer lifetime, and tailored spectrum (Bula et al., 1991). Enhanced growth of Cymbidium plantlets cultured in vitro under red plus blue LEDs was demonstrated in a report by Tanaka et al. (1998). Nhut et al. (2003) also showed that both in vitro and subsequent growth of strawberry plantlets were improved under $30 \%$ blue plus $70 \%$ red LEDs. Furthermore, many studies have showed that LEDs were more suitable for ex vitro and in vitro plant growth than fluorescent lamps (Olle and Virsile, 2013; Gupta and Jatothu, 2013). However, a disadvantage of traditional lighting systems sources and many LED lighting systems on the market is the inconsistent light intensity distribution on the culture shelves (Chen, 2005; Bornwaber, 2012). There are some special systems for plant quality improvements in which LEDs were used as an artificial light source. These lighting systems included LED PACK, BIOLED, UNIPACK and COMPACK (Okamoto et al., 1996). Among them, UNIPACK has improved space utilization, effective wave length utilization, lighting efficiency. However, one of the main obstacles of UNIPACK was to use a lot of wires to supply direct current for LED boards, which makes this system tend to be more complex.

In 2007, Wireless power transmission experimentally demonstrated by a MIT (Massachusetts Institute of Technology) team, allowed energy transmission without wires (Kurs et al., 2007). In that study, a new LED system using the blue-red LEDs ratio of 30 to 70 in combination with wireless power transmission was developed. The major objective of this study was to compare the PPFD distribution of different lighting systems on the surface of the culture shelf. Moreover, investigations of the growth of chrysanthemum and strawberry cultured in vitro under the new LED system and subsequent ex vitro growth were also carried out.

\section{MATERIALS AND METHODS}

\section{Plant materials}

Axillary buds, collected from there-month plants of Chrysanthemum morifolium cv. "Jimba", were washed under running tap water for $30 \mathrm{~min}$ and soaked in $70 \%$ ethanol for $30 \mathrm{~min}$, followed by 7-8 min sterilization with a diluted solution of $\mathrm{HgCl}_{2}(0.1 \% \mathrm{w} / \mathrm{v})$. After that, the buds were rinsed two or three times with sterilized distilled water prior to culture in $100 \mathrm{~mL}$ glass vessels containing $20 \mathrm{~mL}$ MS (Murashige and Skoog 1962) solid medium supplemented with $0.5 \mathrm{mg} \mathrm{L}^{-1}$ benzyl adenine (BA) and $30 \mathrm{~g} \mathrm{~L}^{-1}$ sucrose to induce adventitious shoots.

One-year-old strawberry (Fragaria ananassa) young leaves, were surfacesterilized with $70 \%(\mathrm{v} / \mathrm{v})$ of ethyl alcohol for $30 \mathrm{~s}$ and $0.1 \%\left(\mathrm{HgCl}_{2}\right)$ for $5 \mathrm{~min}$ followed by 4 times rinses with sterile distilled water. These leaves were cut into round discs of $0.8 \mathrm{~cm}$ diameter. Leaves discs were cultured in glass bottles $(250 \mathrm{~cm})$ containing $40 \mathrm{~mL}$ of MS medium supplemented with $1 \mathrm{mg} \mathrm{L}^{-1}$ thidiazuron (TDZ), $0.1 \mathrm{mg} \mathrm{L}^{-1}$ indole-3-butyric acid (IBA), $30 \mathrm{~g} \mathrm{~L}^{-1}$ sucrose and $8.5 \mathrm{~g} \mathrm{~L}^{-1}$ agar for adventitious shoot formation. Eightweek-old shoot clusters were transferred to MS media supplemented with $0.2 \mathrm{BA} \mathrm{mg} \mathrm{L}^{-1}$ $30 \mathrm{~g} \mathrm{~L}^{-1}$ sucrose and $8.5 \mathrm{~g} \mathrm{~L}^{-1}$ agar for shoot elongation.

All cultures were maintained at $20 \pm 2{ }^{\circ} \mathrm{C}$ under fluorescent light at $45 \pm 1 \mu \mathrm{mol} \mathrm{m} \mathrm{m}^{-2} \mathrm{~s}^{-1}$ PPFD with a $16 \mathrm{~h}$ photoperiod. The medium's $\mathrm{pH}$ was adjusted to 5.8 prior to autoclaving at $121^{\circ} \mathrm{C}$ for $30 \mathrm{~min}$.

\section{Culture conditions and light sources}

Five $1.5 \mathrm{~cm}$ height chrysanthemum shoots and five $2.0 \mathrm{~cm}$ height strawberry shoots were cultured in each Magenta ${ }^{\mathrm{TM}}$ GA-7 vessel (77 mm x $77 \mathrm{~mm}$ x $97 \mathrm{~mm}$, Sigma-Aldrich Co. LLC.) containing $70 \mathrm{~mL}$ medium. The medium used for in vitro culture of strawberry shoots 
was MS supplemented with $0.02 \mathrm{mg} \mathrm{L}^{-1} \mathrm{NAA}$ and $1 \mathrm{~g} \mathrm{~L}^{-1} \mathrm{AC}$, while chrysanthemum shoots were cultured on hormone- free MS medium for rooting. These Magenta vessels were placed under LED tubes with the combination of $70 \%$ red and 30\% blue LEDs (CSV Co. Ltd., Viet Nam), the new LED system (details of blue to red light ratios of LED tubes and the structure of new LED system are shown below) and plant growth fluorescent lamps as control.

\section{LED uni-Pack (LP)}

The structure of the LED uni-Pack (LP) system is presented in Figure 1. Magenta vessels were covered by rectangular acrylic plastic lids [ $8 \mathrm{~cm}$ (Length), $2 \mathrm{~cm}$ (Height), $8 \mathrm{~cm}$ (Width)]. As a light source, the LED board with many pieces of LEDs was mounted on the ceiling of the acrylic plastic lid. The LED arrangement of this board consisted on 4 rows with 20 red LEDs and 3 rows with 9 blue LEDs so that the ratio of red LED to blue LED was close to 7:3. Direct current (DC) supply and electrical circuit were provided on the backside of the LED uni-Pack. The PPFD of the systems was adjusted by using the voltage control.
Transmitter device: This device, including a transformer circuit, a rectifier circuit, an oscillation circuit, an amplifier circuit, and a LC circuit, was connected to a power source and converted the input power to oscillating electromagnetic fields. The transformer circuit converted the input power from $220 \mathrm{~V}$ (Alternating current - AC) to 60V (AC) and 24V (AC). Then, the rectifier circuit converted the alternating current to direct current with two sources: a $15 \mathrm{~V}$ power supply for oscillation circuit and an $80 \mathrm{~V}$ power supply at high-voltage for LC circuit. The oscillation circuit created oscillation for the LC circuit. The amplifier circuit was responsible for supplying maximum power to the load, as efficiently as possible. The LC resonant circuit was used for obtaining resonance and signal transfer. Signals were transmitted in the form of electromagnetic waves with a frequency range from $100-130 \mathrm{kHz}$.

Receiver device: This device converted electromagnetic waves back to electric power and utilization. The receiver circuit included LC resonant circuit which resonated the electromagnetic signals and the load was made possible by the LED board.

Wireless power transmission - LED uni-Pack (WPT - LP)
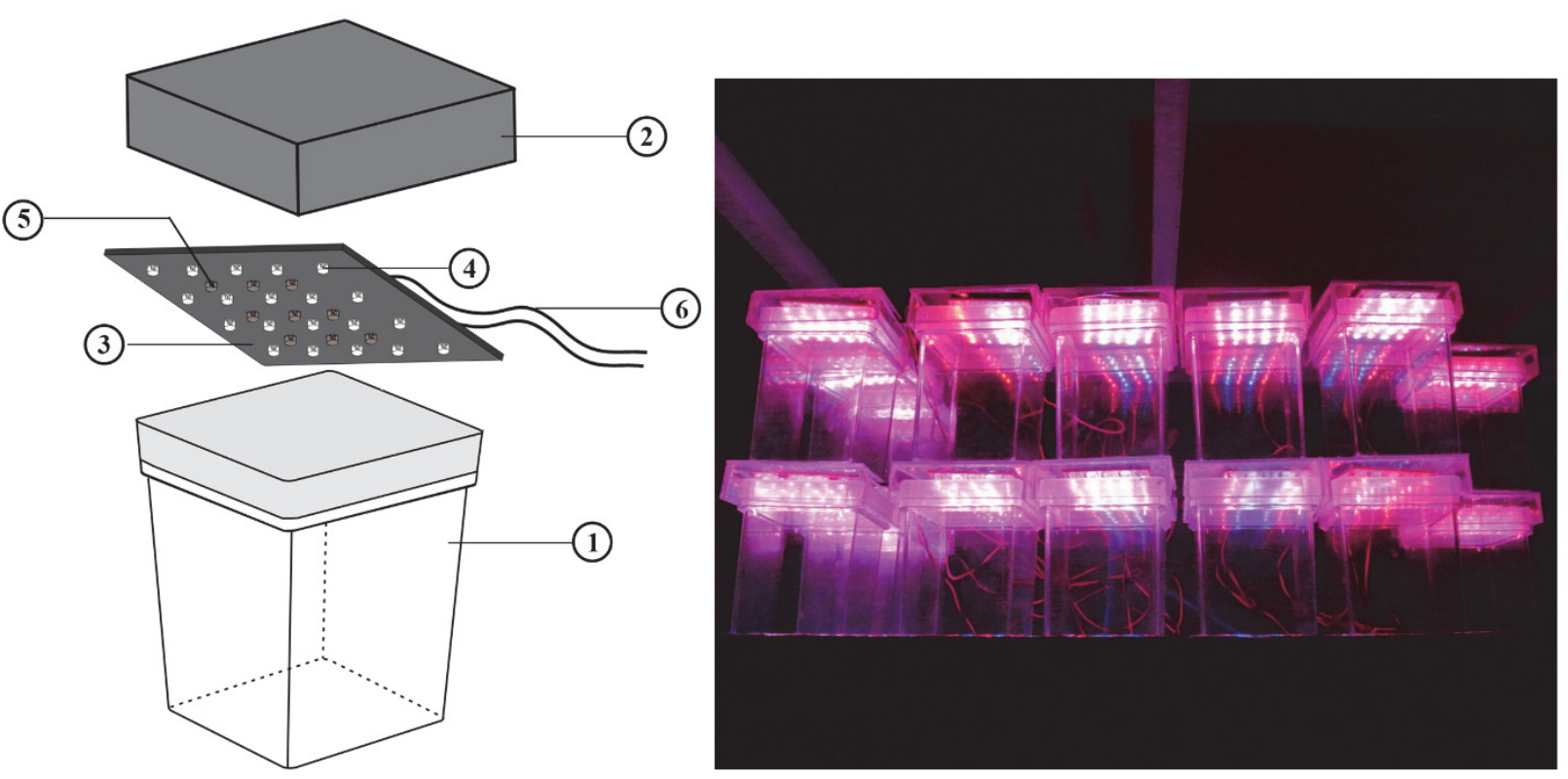

Figure 1 - Diagram of the LP system (left). (1) magenta vessel, (2) the acrylic plastic lid, (3) LED board, (4) blue LED, (5) red LED, (6) direct current input; the operation of the LP systems (right). 
Like the LP system, the LED board light source of WPT-LP system was also arranged in 4 rows with 20 red LEDs and 3 rows with 9 blue LEDs so that the ratio of red LED to blue LED was close to $7: 3$. In addition, the light intensity for the systems was adjusted by changing the frequency of the transmitter device. The structure of WPT-LP system is shown more detail in Figures 2A, B; 3A, B, C, D.

The lights were positioned above the cultures and the PPFD was adjusted to $45 \pm 1 \mu \mathrm{mol} \mathrm{m} \mathrm{m}^{2} \mathrm{~s}^{-1}$ (under bottom of the magenta vessel) with a $16 \mathrm{~h}$ photoperiod. The PPFD was measured by a light meter (LI-COR250A, Lincoln, NE, USA) with a quantum sensor (LI-190, LI-COR Inc., USA).

\section{Acclimatization}

After 4 weeks of culture, the chrysanthemum and strawberry plantlets were taken out from magenta vessels and the roots were washed under running tap water in order to remove the agar and solid medium. The plantlets were dipped in a solution of fungicides $0.4 \% \mathrm{w} / \mathrm{v}$ (Ridomil gold 68WP, Syngenta) for 10 minutes and then washed with tap water. Plantlets were planted into black nylon bags containing a mixture of organic soil and sand $(1: 1)$ with a $\mathrm{pH}$ of 6.5 , then placed in a plastic tunnel in the greenhouse (under the natural light of no more than $200 \mu \mathrm{mol} \mathrm{m} \mathrm{m}^{-2} \mathrm{~s}^{-1}$ with sunshade nets, at $18-25^{\circ} \mathrm{C}$, and $80-90 \%$ relative humidity). After 2 weeks, the relative humidity was slowly reduced by gradually removing the cover. All plants grew under natural light conditions and were irrigated with water once per day.

\section{Data collection and statistical analysis}

Nine culture vessels were placed on the surface of the shelf with an area of

\section{(A)}

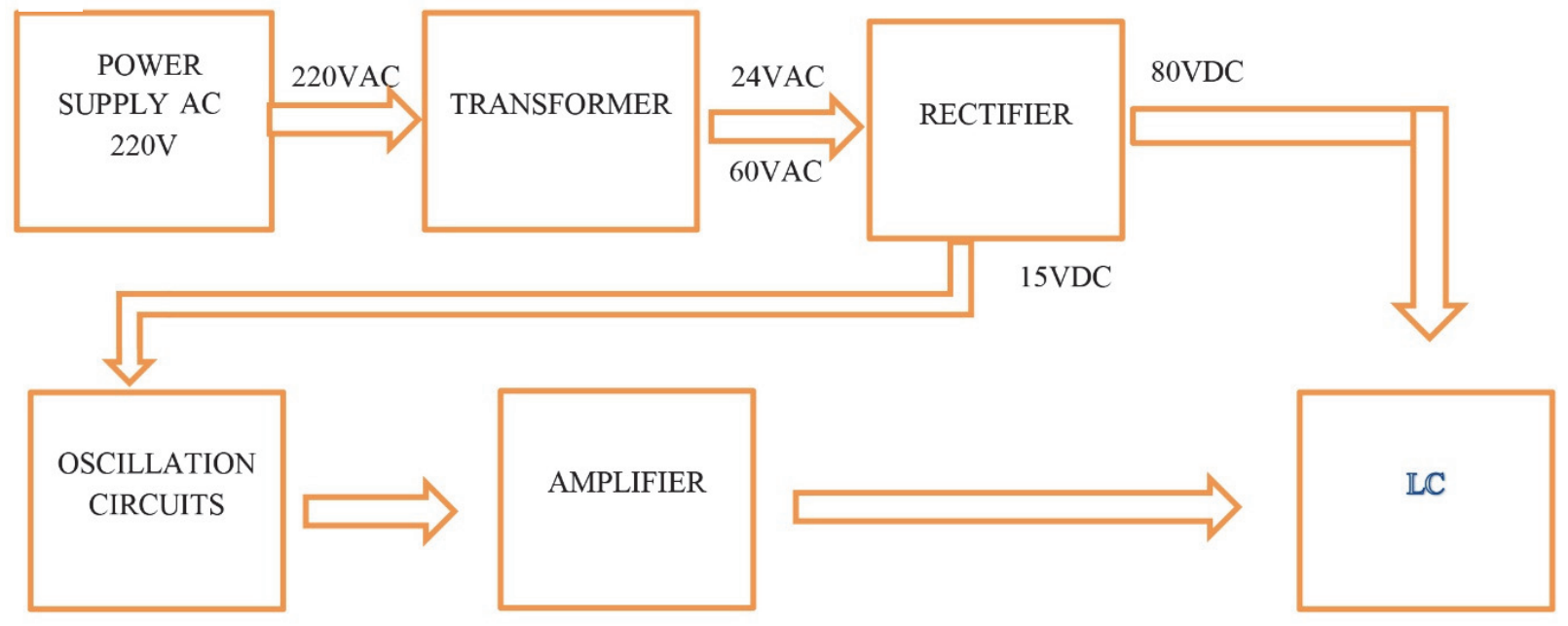

(B)

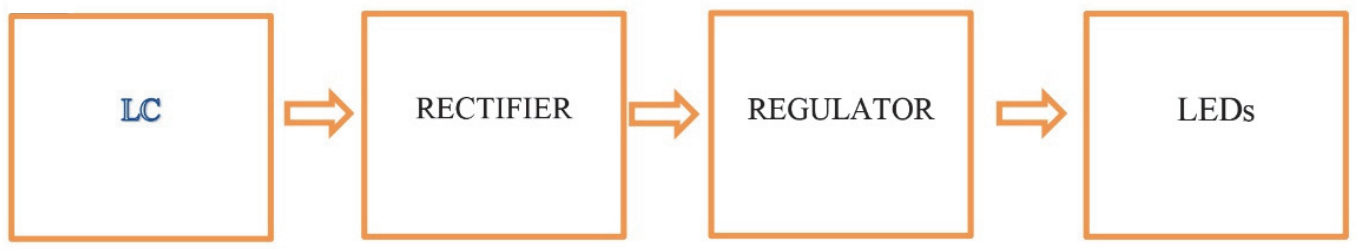

Figure 2 - Block diagrams of the circuit setup in WPT-LP system. (A) Output circuit (receiver); (B) Input circuit (transmitter). 


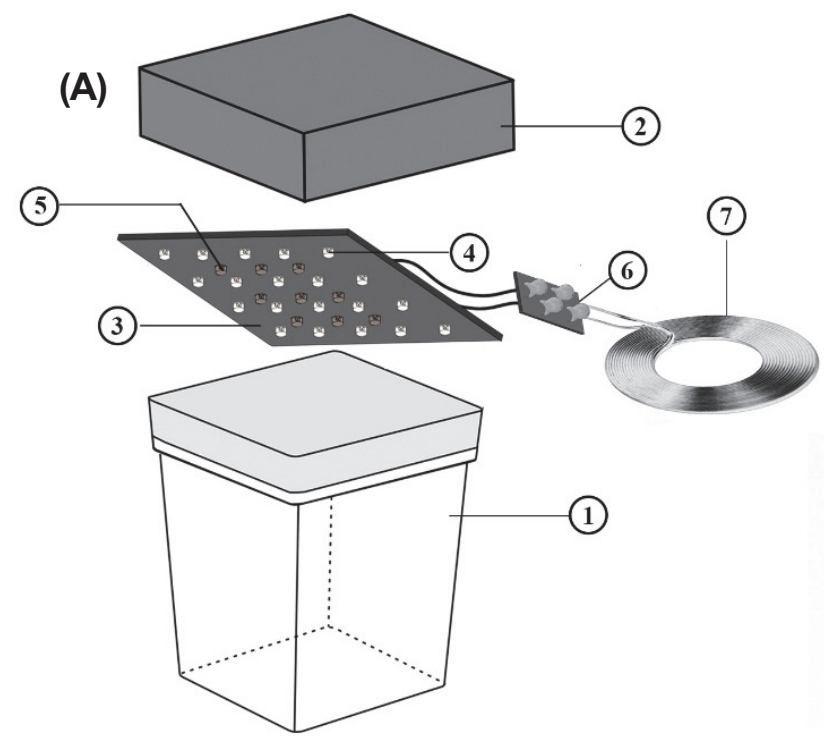

(B)
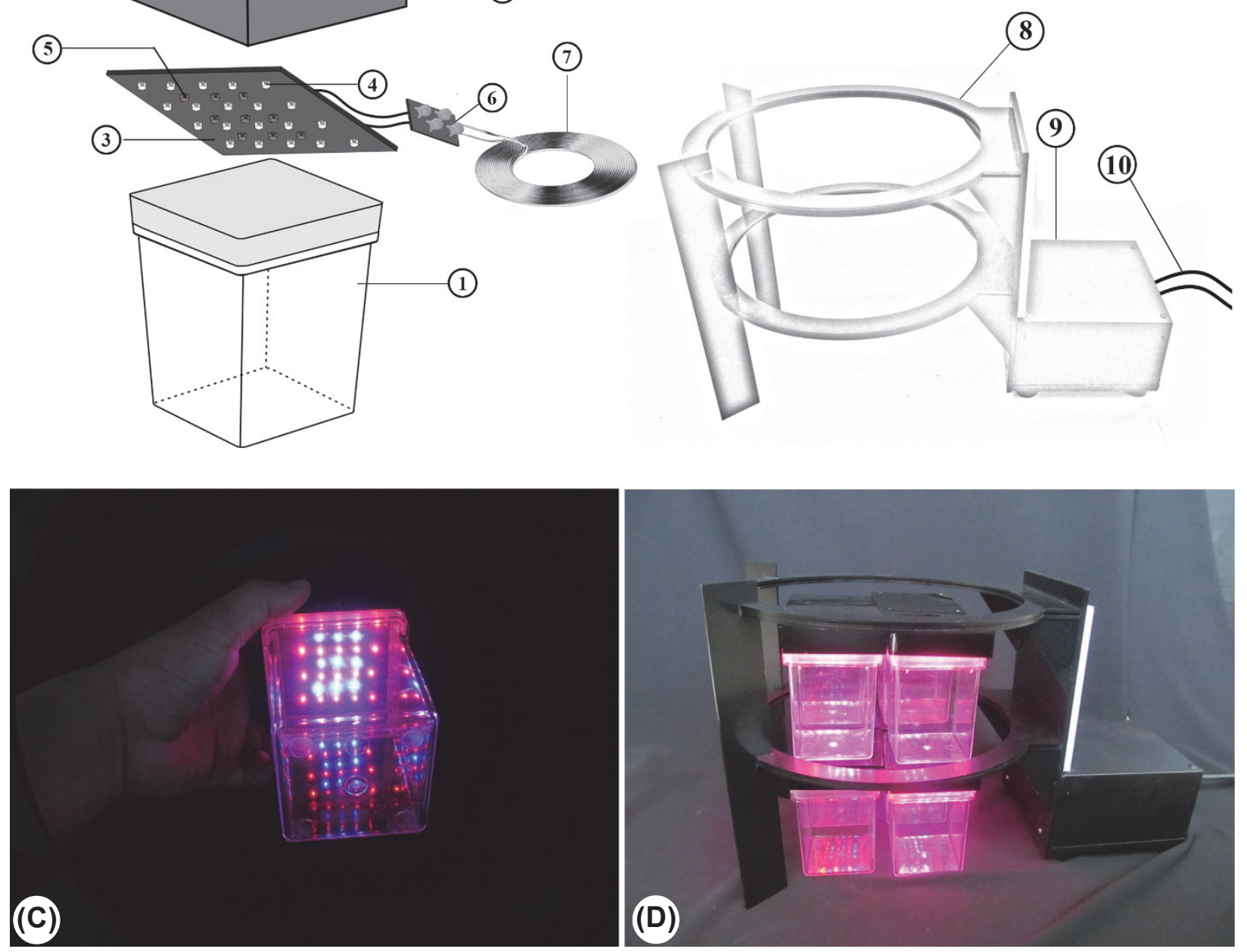

Figure 3 - Diagram of the WPT-LP system. (A) receiver device: (1) magenta vessel; (2) The acrylic plastic lid; (3) LED board; (4) blue LED; (5) red LED; (6) rectifier and regulator; (7) Receiver coil; (B) transmitter device: (8) Transmitter coil, (9) Wireless power transmitter circuit, (10) Main power supply; (C-D) the operation of WPT-LP system.

$30 \mathrm{~cm} \times 30 \mathrm{~cm}$. The PPFD was determined at 49 measuring points in a distance of $5 \mathrm{~cm}$ to each other on the shelf board $(30 \mathrm{~cm} \times 30 \mathrm{~cm})$ by a light meter (Figure 5B). The distance between the fluorescent lamps or LED tubes and the surface of the shelf was $30 \mathrm{~cm}$ (Figure 5A). The distance between the light source of the LP or WPT-LP systems and the bottom of the culture vessel was $9.70 \mathrm{~cm}$ (the height of magenta box). The PPFD distribution of LED tube, LP system, WPT-LP system and fluorescent lamp was drawn by using the Surfer software version 11.0 (Golden software, Inc., USA).
Fresh weight, dry weight, root number, root length, plant height, leaf number and internode length of in vitro chrysanthemum and strawberry plantlets were collected after 4 weeks. Additionally, internode length of 4week-old chrysanthemum plantlets was also determined. The survival rate, plant fresh weight, plant height and leaf area of ex vitro plants were recorded after 6 weeks for chrysanthemum and 4 weeks for strawberry. Leaf areas of four fully developed leaves, counted from the plantlets' top, downward, were recorded by a leaf area meter (LI-3000C (LI-COR Biosciences UK Ltd.), whereas the 
chlorophyll content was measured by a spectrophotometer UV - 2900 (Hitachi, Japan). Leaves were harvested and the fresh weight $(1 \mathrm{~g})$ of each sample was added in test tubes containing $50 \mathrm{~mL}$ acetone $(80 \%)$ and placed in dark condition for $24 \mathrm{~h}$ to completely extract chlorophyll (Chl) until the leaf material turned white. The optical density was measured with a spectrophotometer UV - 2900 at $662 \mathrm{~nm}$ for Chl a, and at $645 \mathrm{~nm}$ for Chl b. The concentrations of $\mathrm{Chl} \mathrm{a}$ and $\mathrm{Chl} \mathrm{b}$ were determined from the following formula (Lichtentaler andWellburn, 1985):

$$
\begin{aligned}
& \text { Chlorophyll } \mathrm{a}=\left(11.75^{*} \mathrm{~A} 662-2.35 * \mathrm{~A} 645\right) \\
& \text { Chlorophyll } \mathrm{b}=(18.61 * \mathrm{~A} 645-3.96 * \mathrm{~A} 662)
\end{aligned}
$$

All experiments were set up in a completely randomized design and the data were collected from three replicates and average values were subjected to Duncan's multiple range test (Duncan, 1955) using SPSS software version 16.0 (SPSS Inc., USA).

\section{RESULTS AND DISCUSSION}

\section{Evaluation of the PPFD distribution and the space use efficiency of different lighting systems}

The PPFD that affected directly on plantlets growth and photosynthesis was one of the most important conditions in micro-propagation (Kozai et al., 1997; Kim et al., 2004). The PPFD strongly depended on different locations of the shelf when the fluorescent lamps or LED tubes were installed as light source for the culture vessels (Bornwaber and Tantau, 2012). As shown in (Figure 4C, D), maximum PPFD values of fluorescent lamp $\left(45 \mu \mathrm{mol} \mathrm{m}^{-2} \mathrm{~s}^{-1}\right)$ and LED tube $\left(46.7 \mu \mathrm{mol} \mathrm{m}^{-2} \mathrm{~s}^{-1}\right)$ were found in the central region of shelf culture. These values decreased quickly near the edge region. The fluorescent lamp and LED tube showed different PPFDs in different regions on the shelf. As a result, it was very difficult to set up the uniform PPFD for the culture vessels. The uniform distribution of PPFD in the lighting systems plays an important role in the maintenance of plantlets quality (Chen, 2005). In our study, the PPFD of LP and WPT-LP system was maintained at $45 \mu \mathrm{mol} \mathrm{m}{ }^{-2} \mathrm{~s}^{-1}$ at the bottom of the vessel (Figure 4E). Another advantage of the LP and WPT-LP systems is that their PPFD focused on the culture vessel and avoided the wastage of light.

In order to improve space usage efficiency in culture room, Hayashi et al. (1992) developed a sideward lighting system using fluorescent lamps. However, when using this lighting system, space was needed to install the lamp and to have the distance between culture vessels and the light source because the fluorescent lamps emitted heat (Chen, 2005; Tanaka et al., 2009). The fluorescent lamps are placed $30-50 \mathrm{~cm}$ above the vessels in order to avoid temperature increase inside the vessels in the conventional downward lighting system (Kitaya et al., 1995).

Light-emitting diodes (LEDs) have been proposed as an alternative promising light source for plant tissue culture. LEDs were continuously improved for more efficient light sources. LEDs generated very little heat when emitting light. Therefore, the distance between the light sources and culture vessels could be shorter. LED tubes and LED panels are commercially available and can be used to replace FL for lighting in the culture room, however, there has been virtually no increase in the space usage efficiency of shelves. To increase energy efficiency and the space utilization of the culture room, a UNIPACK tissue culture lighting system was developed by Okamoto et al. (1996). The UNIPACK consists of a cultural vessel $(11 \mathrm{~cm} \mathrm{x}$ $11 \mathrm{~cm} \mathrm{x} 14 \mathrm{~cm}$ ) and a light source named LEDCAP containing 9 blue LEDs and 36 red LEDs. In our present study, LED board of the LP system was designed according to the system developed by Okamoto containing 9 blue LEDs and 20 red LEDs. Like UNIPACK, the culture vessel of LP and WPT-LP system can be arranged with multiple layers to increase the space use efficiency of shelves. With the LP system a lot of wires were used to supply direct current for LED board of the LP so this system structure became complex. To solve this problem, wireless power transfer technology is used in WPT-LP system. Scaling up simulation models of WPT-LP system in plant tissue culture is showed in Figure 5 (right), in this case, the number of layers of the culture vessel depends on the number of the transmitter coils. For instance, the 
(A)

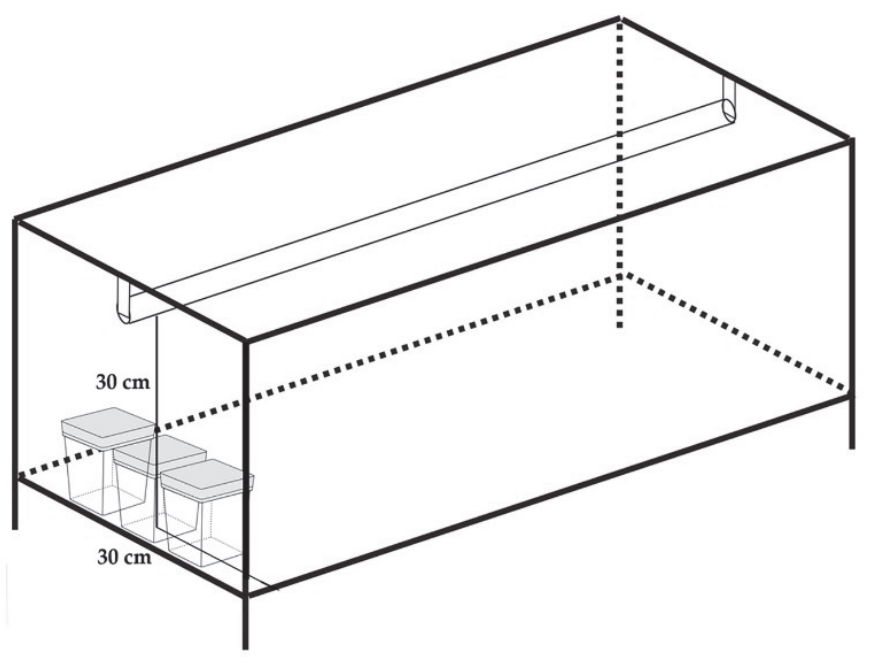

(C)
(B)

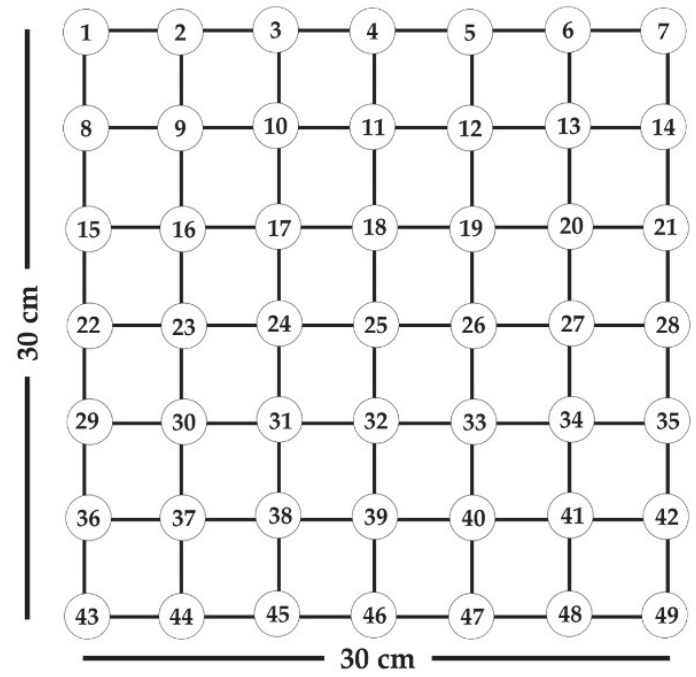

(D)

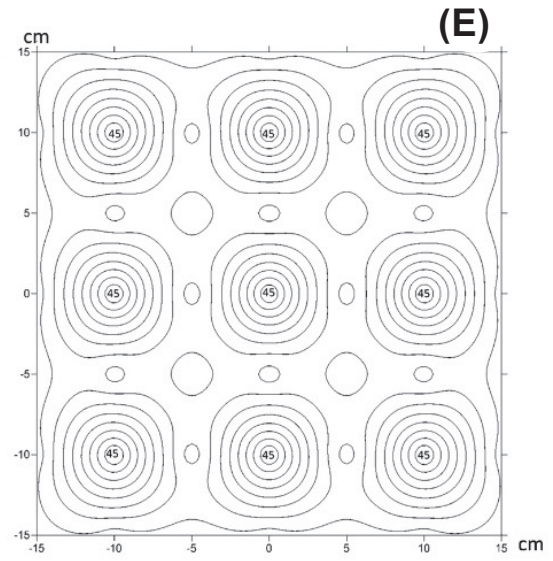

Figure 4 - The PPFD distribution $\left(\mu \mathrm{mol} \mathrm{m} \mathrm{m}^{-2} \mathrm{~s}^{-1}\right.$ ) of different lighting systems. (A) general layout of the culture vessel; (B) the measured point of the PPFD on the shelf; (C) fluorescent lamp; (D) LED tube with $30 \%$ blue plus $70 \%$ red LED; (E) the LP and WPT-LP systems.
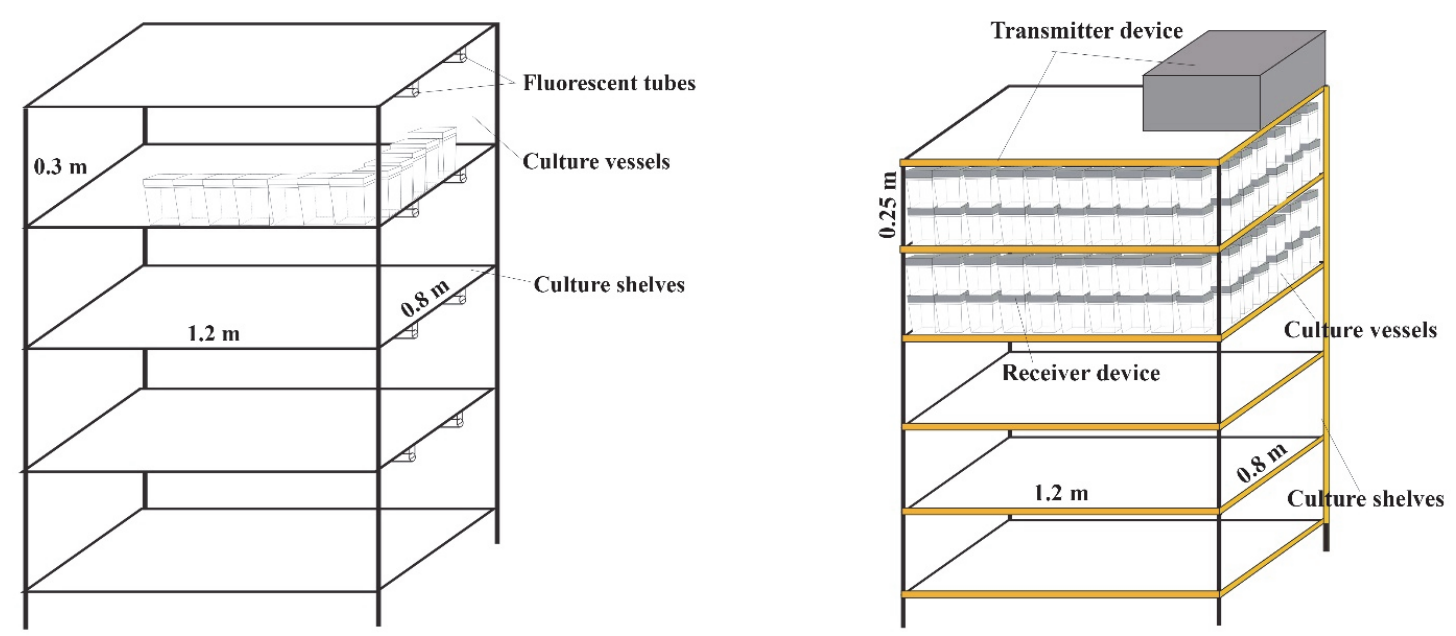

Figure 5 - The conventional lighting system using fluorescent tubes (left) and scaling up simulation models of WPT-LP system (right) in plant tissue culture. 
volume of the culture shelves was $0.24 \mathrm{~m}^{3}$ $(1.2 \mathrm{~m} \times 0.8 \mathrm{~m} \times 0.25 \mathrm{~m})$. With 6 transmitter coils in WPT-LP system, one culture shelf contained 10 layers of the Magenta culture vessels and one layer consisted of 96 Magenta culture vessels $(77 \mathrm{~mm} \times 77 \mathrm{~mm} \times 97 \mathrm{~mm})$. Thus, each culture shelf contained 192 vessels in WPT-LP system. In the conventional lighting system, the height of light source was $30 \mathrm{~cm}$. The distance of the fluorescent lamp from the top of the Magenta culture vessel was $20 \mathrm{~cm}$, thus, the culture shelf only contained 96 vessels. For this reason, space efficiency of WPT-LP system can be increased 2 times in comparison with the conventional lighting system per same culture area (Figure 5).

\section{Effect of various lighting systems using ratio of $30 \%$ blue plus $70 \%$ red LEDs on the in vitro growth of chrysanthemum plantlets and subsequent ex vitro growth}

The effect of different lighting systems on the in vitro growth of chrysanthemum plantlets for 4 weeks was shown in Table 1 and Figure 6 . The results indicated that the growth of chrysanthemum plantlets under LED lighting systems was significantly higher than that of FL light treatment. There was no significant difference among the plant height of plantlets under LED tube, LP and WPT-LP system. The lowest height value $(4.56 \mathrm{~cm})$ was observed under FL. A similar result was observed for the plantlet fresh weight, and it was higher under LP (1.43 g per plantlet) and WPT-LP (1.42 g per plantlet) than under LED tube ( $1.13 \mathrm{~g}$ per plantlet) and FL (0.83 g per plantlet) (Table 1). The number of leaves per plantlet under LED lighting systems was higher than that under FL. Moreover, the internode was longer in plantlets under WPTLP system, intermediate in plantlets under LED tube and LP system and shorter in plantlets under fluorescent lamp. However, the number of leaves per plantlet under fluorescent lamp was higher than that under LED lighting systems (Table 3). The root growth of plantlets also varied in response to the different lighting systems. The highest number of roots per plantlet was found under LP system. Meanwhile, the root length was higher under FL and LP systems. In contrast, under LED tubes, root growth was the poorest among the lighting system treatments. Besides, chlorophyll $a+b$ contents of chrysanthemum leaves under LED lighting systems were higher than those of plantlets under FL. However, there was no statistically significant differences among chlorophyll concentration under LP and WPT-LP system. Our results showed that the LP and WPT-LP systems with the ratio of $30 \%$ blue plus $70 \%$ red LEDs were suitable for chrysanthemum plantlets cultured in vitro.

Different lighting systems during in vitro culture also affected the subsequent acclimatization of chrysanthemum to ex vitro conditions. The subsequent growth of chrysanthemum plantlets, cultured in vitro under LED tube, LP and WPT-LP system that used ratio of $30 \%$ red plus $70 \%$ blue LED and FL for 4 weeks transferred to soil for 6 weeks, is shown in Table 2. Plants acclimatized and grew well after transferred to soil in all the treatments. There were significant differences in survival rate, fresh weight and plant height. The survival rate of chrysanthemum plantlets under FL control was lower when compared to those under other lighting systems.

Table 1 - Effect of different lighting systems on in vitro chrysanthemum growth and development

\begin{tabular}{|l|c|c|c|c|c|c|c|c|c|}
\hline $\begin{array}{c}\text { Lighting } \\
\text { system }\end{array}$ & $\begin{array}{c}\text { Fresh } \\
\text { weight } \\
(\mathrm{g})\end{array}$ & $\begin{array}{c}\text { Dry } \\
\text { weight } \\
(\mathrm{mg})\end{array}$ & $\begin{array}{c}\text { Root } \\
\text { number }\end{array}$ & $\begin{array}{c}\text { Root } \\
\text { length } \\
(\mathrm{cm})\end{array}$ & $\begin{array}{c}\text { Plant } \\
\text { height } \\
(\mathrm{cm})\end{array}$ & $\begin{array}{c}\text { Leaf } \\
\text { number }\end{array}$ & $\begin{array}{c}\text { Leaf area } \\
\left(\mathrm{cm}^{2}\right)\end{array}$ & $\begin{array}{c}\text { Root } \\
\text { length } \\
\left(\mathrm{cm}^{2}\right)\end{array}$ & $\begin{array}{c}\text { Chlorophyll } \\
\mathrm{a}+\mathrm{b}\left(\mu g \mathrm{~g}^{-1}\right)\end{array}$ \\
\hline FL & $0.83 \mathrm{c}$ & $71.35 \mathrm{c}$ & $13.00 \mathrm{~b}$ & $5.84 \mathrm{a}$ & $4.56 \mathrm{~b}$ & $14.00 \mathrm{a}$ & $2.93 \mathrm{~b}$ & $0.33 \mathrm{c}$ & $31.8 \mathrm{c}$ \\
\hline LED & $1.13 \mathrm{~b}$ & $91.78 \mathrm{~b}$ & $12.40 \mathrm{c}$ & $3.00 \mathrm{c}$ & $5.22 \mathrm{a}$ & $12.60 \mathrm{ab}$ & $3.45 \mathrm{a}$ & $0.41 \mathrm{~b}$ & $44.7 \mathrm{~b}$ \\
\hline LP & $1.43 \mathrm{a}$ & $119.56 \mathrm{a}$ & $16.20 \mathrm{a}$ & $5.22 \mathrm{a}$ & $5.64 \mathrm{a}$ & $12.60 \mathrm{ab}$ & $3.53 \mathrm{a}$ & $0.45 \mathrm{~b}$ & $49.3 \mathrm{a}$ \\
\hline WPT-LP & $1.42 \mathrm{a}$ & $118.67 \mathrm{a}$ & $13.40 \mathrm{~b}$ & $4.73 \mathrm{ab}$ & $5.68 \mathrm{a}$ & $10.60 \mathrm{~b}$ & $3.59 \mathrm{a}$ & $0.53 \mathrm{a}$ & $47.9 \mathrm{ab}$ \\
\hline
\end{tabular}

Different letters in the same column indicate significant differences in Duncan's test (p-value $\leq 0.05$ ). 


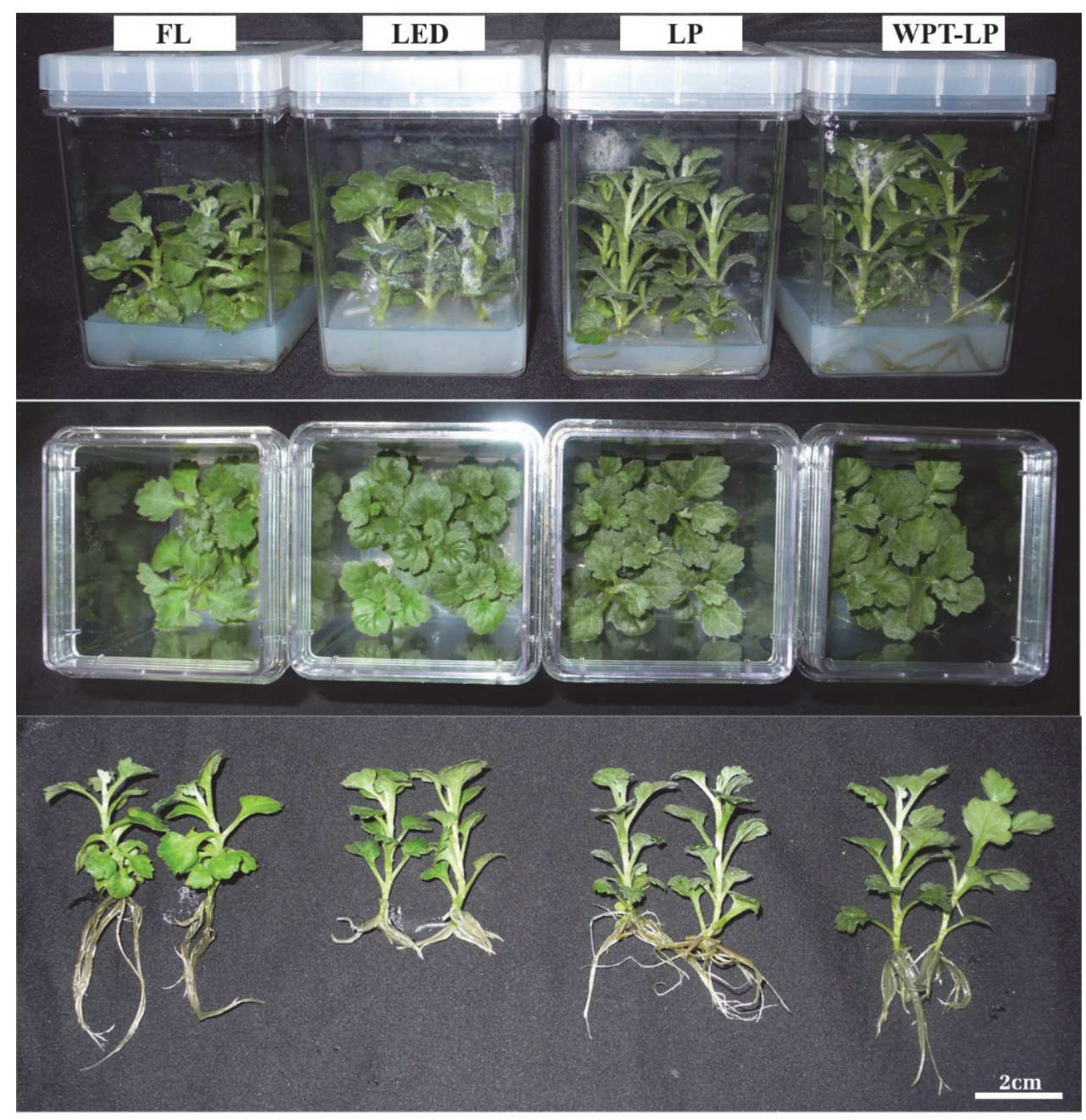

Figure 6 - Effect of various lighting systems (FL, LED tube, LP and WPT-LP system) on in vitro chrysanthemum growth and development.

Table 2 - Effect of different lighting systems on subsequent ex vitro chrysanthemum growth and development in greenhouse after 6 weeks

\begin{tabular}{|l|c|c|c|c|}
\hline \multicolumn{1}{|c|}{ Lighting system } & Survival rate (\%) & Fresh weight $(\mathrm{g})$ & Plant height $(\mathrm{cm})$ & Leaf area $\left(\mathrm{cm}^{2}\right)$ \\
\hline FL & $94 \mathrm{~b}$ & $4.32 \mathrm{c}$ & $10.00 \mathrm{~b}$ & $18.15 \mathrm{a}$ \\
\hline LED & $98 \mathrm{a}$ & $4.71 \mathrm{bc}$ & $11.90 \mathrm{a}$ & $18.96 \mathrm{a}$ \\
\hline LP & $100 \mathrm{a}$ & $5.27 \mathrm{a}$ & $11.94 \mathrm{a}$ & $19.55 \mathrm{a}$ \\
\hline WPT-LP & $100 \mathrm{a}$ & $5.04 \mathrm{ab}$ & $12.00 \mathrm{a}$ & $18.02 \mathrm{a}$ \\
\hline
\end{tabular}

Different letters in the same column indicate significant differences in Duncan's test (p-value $\leq 0.05$ ).

The survival rate of chrysanthemum plantlets derived from cultivation under LED lighting system was significantly higher than that under FL. In addition, the height and fresh weight of chrysanthemum plantlets were also higher in LP and WPT-LP when compared to those under FL light treatment. Growth continued until flower bud formation from chrysanthemum plantlets under different lighting systems (FL, LED tube, LP and WPT-LP system) after transferred to soil for 16 weeks (Figure 7). 


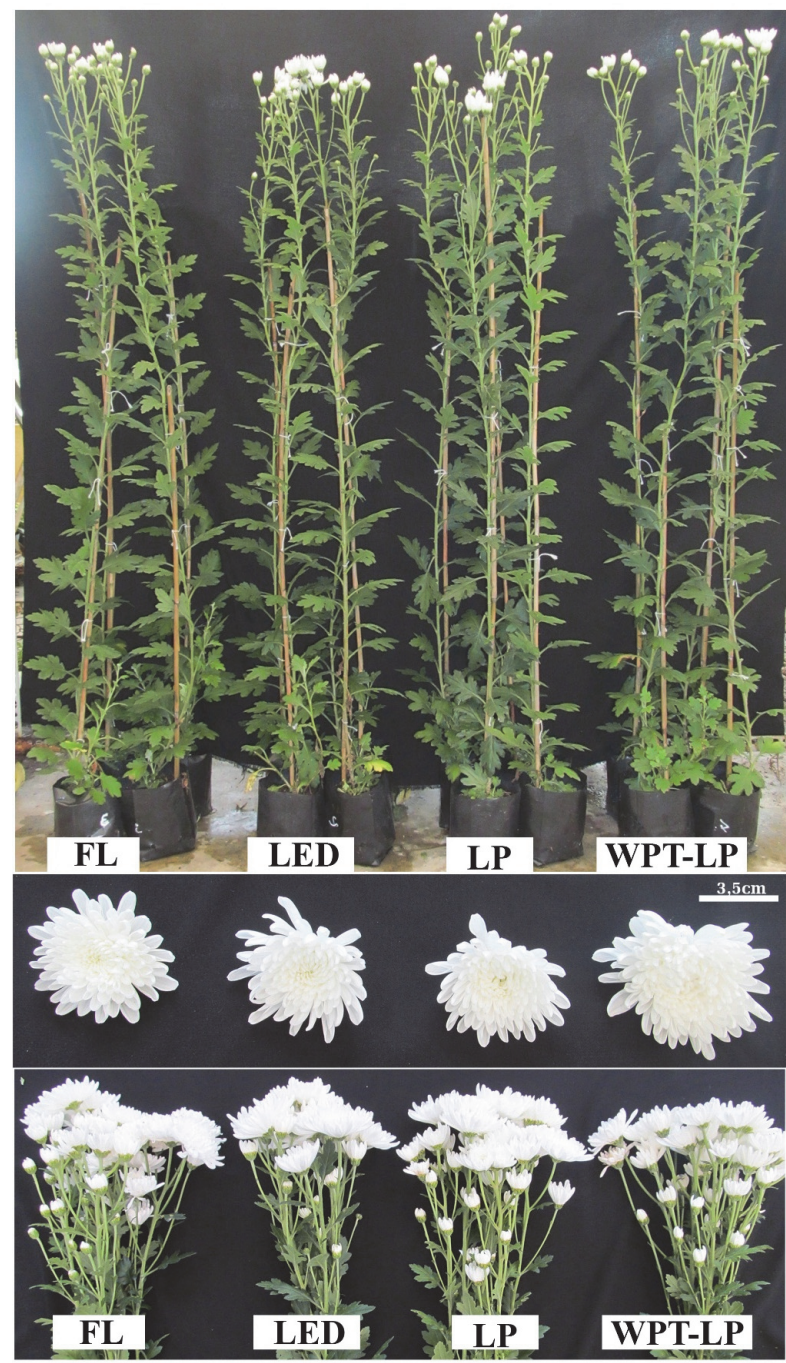

Figure 7 - A comparison of subsequent growth of in vitro chrysanthemum plantlets under different lighting systems (FL; LED tube; LP system; WPT-LP system) after transferring to soil for 16 weeks.

There were many researches that demonstrated the combination of blue LEDs and red LEDs as an effective light source for in vitro plant growth. The early research of this combination on enhanced growth of Cymbidium plantlets cultured in vitro was reported by Tanaka et al. (1998). Lian et al. (2002) also found that red plus blue LEDs were suitable for growth of bulblets of Lilium and the number of root per bulblet and the fresh and dry weight matter percentage of bulblets grown under this condition were higher than the bulblets under fluorescent lamps. The effects of LEDs on the growth of Chrysanthemum were reported by Kim et al. (2004). In their study, net photosynthetic rate of Chrysanthemum was higher under red plus blue LEDs, followed by fluorescent lamps and lower under blue plus far-red LEDs and blue LEDs (Kim et al., 2004). Our experiment has shown that the combination of red and blue LED in three systems (LED, LP and WPT-LP) promoted increase in the growth and development parameters of in vitro and ex vitro Chrysanthemum plantlets (Table 1 and 2). Chrysanthemum plantlets grown very well when cultured in LP and WPT-LP systems under in vitro conditions and subsequent growth in greenhouse.

\section{Effect of various systems using ratio of $30 \%$ blue plus $70 \%$ red LEDs on the in vitro growth of strawberry plantlets and subsequent growth when transferred to soil}

After 4 weeks of culture, the growth parameters of in vitro strawberry plantlets growth under different systems is presented in Table 3. According to our data, strawberry plantlets grown under LED lighting systems had higher fresh, dry weight and plant height than those grown under fluorescent light (Table 3; Figure 8). The total fresh weight was

Table 3 - Effect of different lighting systems on in vitro chrysanthemum growth and development

\begin{tabular}{|l|c|c|c|c|c|c|c|c|}
\hline $\begin{array}{c}\text { Lighting } \\
\text { system }\end{array}$ & $\begin{array}{c}\text { Fresh } \\
\text { weight }(\mathrm{g})\end{array}$ & $\begin{array}{c}\text { Dry weight } \\
(\mathrm{mg})\end{array}$ & $\begin{array}{c}\text { Plant } \\
\text { height } \\
(\mathrm{cm})\end{array}$ & $\begin{array}{c}\text { Leaf } \\
\text { number }\end{array}$ & $\begin{array}{c}\text { Leaf area } \\
\left(\mathrm{cm}^{2}\right)\end{array}$ & $\begin{array}{c}\text { Root } \\
\text { number }\end{array}$ & $\begin{array}{c}\text { Root } \\
\text { length } \\
(\mathrm{cm})\end{array}$ & $\begin{array}{c}\text { Chlorophyll } \\
\mathrm{a}+\mathrm{b} \\
\left(\mu \mathrm{g} \mathrm{g} \mathrm{g}^{-1}\right)\end{array}$ \\
\hline FL & $0.48 \mathrm{~b}$ & $25.92 \mathrm{~b}$ & $5.26 \mathrm{~b}$ & $5.49 \mathrm{a}$ & $2.10 \mathrm{~b}$ & $5.18 \mathrm{~b}$ & $3.36 \mathrm{c}$ & $39.85 \mathrm{c}$ \\
\hline LED & $1.02 \mathrm{a}$ & $56.81 \mathrm{a}$ & $6.50 \mathrm{a}$ & $6.75 \mathrm{a}$ & $2.72 \mathrm{~b}$ & $10.38 \mathrm{a}$ & $4.99 \mathrm{~b}$ & $43.10 \mathrm{bc}$ \\
\hline LP & $1.04 \mathrm{a}$ & $60.97 \mathrm{a}$ & $6.50 \mathrm{a}$ & $6.98 \mathrm{a}$ & $4.50 \mathrm{a}$ & $11.08 \mathrm{a}$ & $6.13 \mathrm{a}$ & $44.50 \mathrm{~b}$ \\
\hline WPT-LP & $1.02 \mathrm{a}$ & $59.70 \mathrm{a}$ & $6.66 \mathrm{a}$ & $6.49 \mathrm{a}$ & $4.15 \mathrm{a}$ & $11.43 \mathrm{a}$ & $4.57 \mathrm{~b}$ & $48.05 \mathrm{a}$ \\
\hline
\end{tabular}

Different letters in the same column indicate significant differences in Duncan's test ( $\mathrm{p}$-value $\leq 0.05$ ). 

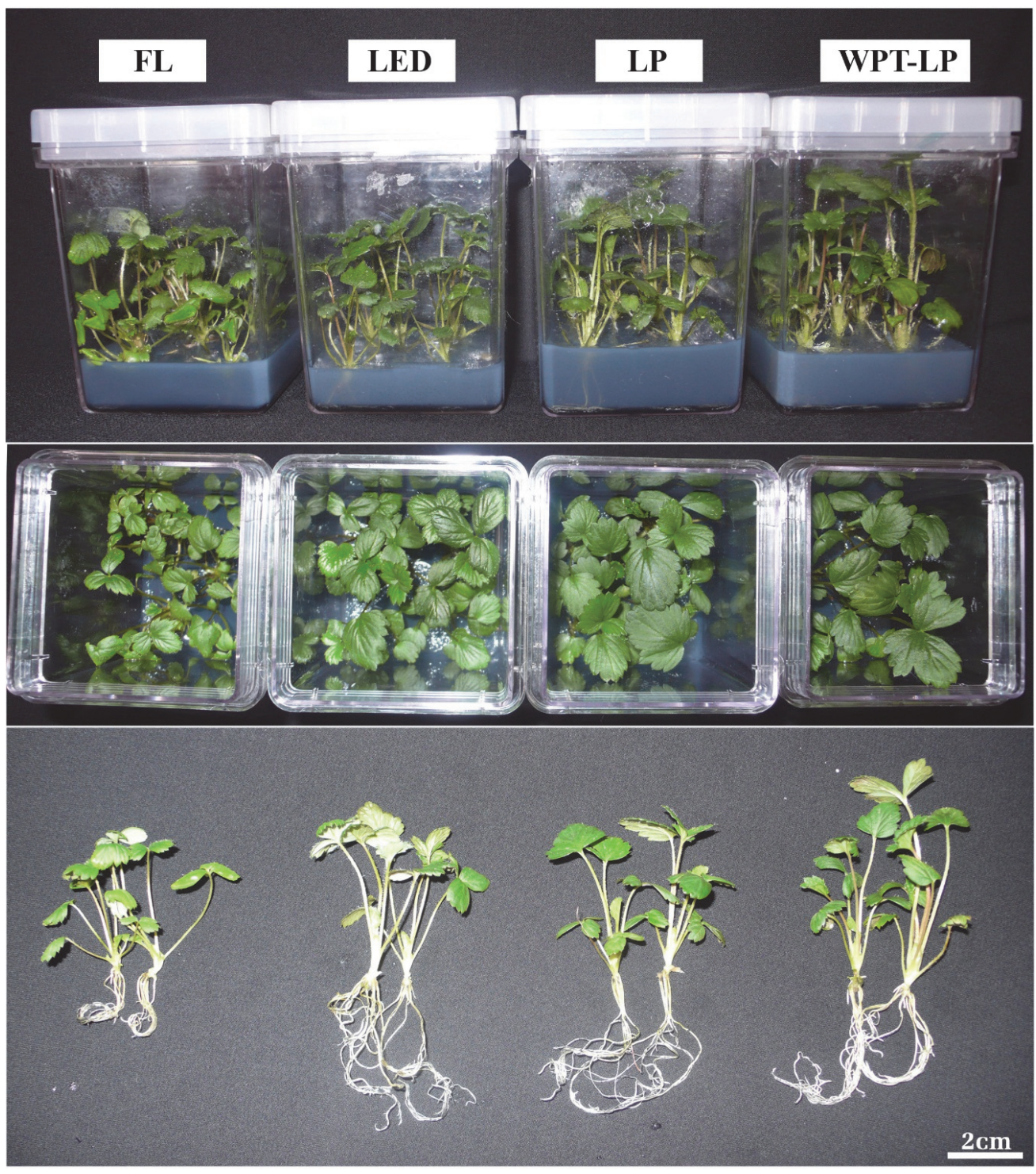

Figure 8 - Effect of various lighting systems (FL, LED tube, LP and WPT-LP system) on in vitro strawberry growth and development.

lower for strawberries grown under FL $(0.48 \mathrm{~g}$ per plantlet) while the observed increase of dry weight under LED, LP and WTP-LP system ranged from 1.02 to $1.04 \mathrm{~g}$ per plantlet over the fresh weight of control plants. No significant difference was observed in the number of leaves of explants among different systems but leaf area was greatly affected by various systems. Leaf area of plantlets were higher under LP system $\left(4.53 \mathrm{~cm}^{2}\right)$, whereas those under FL were the lowest growth observed, with small leaf area $\left(2.10 \mathrm{~cm}^{2}\right)$. In addition, chlorophyll content exhibited significant difference among the different systems.
Chlorophyll content was higher when plantlets were cultured under WTP-LP even though other growth parameters regarding were remarkably lower under this system than those under LP.

Subsequent growth of in vitro strawberry plantlets under different lighting systems (FL; LED tube; LP system; WPT-LP system) after 4 weeks of acclimatization in the greenhouse are presented in Table 4.

The acclimatization of in vitro strawberry plantlets had been variably affected by different lighting systems. Strawberry plantlets cultured in the LED lighting system outperformed by a 
Table 4 - Effect of different lighting systems on subsequent ex vitro strawberry growth and development in greenhouse after 4 weeks

\begin{tabular}{|l|c|c|c|c|}
\hline \multicolumn{1}{|c|}{ Lighting system } & Survival rate (\%) & Fresh weight $(\mathrm{g})$ & Plant height $(\mathrm{cm})$ & Leaf area $\left(\mathrm{cm}^{2}\right)$ \\
\hline FL & $70 \mathrm{~b}$ & $3.01 \mathrm{~b}$ & $6.99 \mathrm{~b}$ & $7.11 \mathrm{~b}$ \\
\hline LED & $94 \mathrm{a}$ & $3.97 \mathrm{~b}$ & $8.75 \mathrm{a}$ & $12.73 \mathrm{a}$ \\
\hline LP & $96 \mathrm{a}$ & $5.35 \mathrm{a}$ & $8.74 \mathrm{a}$ & $13.02 \mathrm{a}$ \\
\hline WPT-LP & $96 \mathrm{a}$ & $5.30 \mathrm{a}$ & $9.33 \mathrm{a}$ & $12.49 \mathrm{a}$ \\
\hline
\end{tabular}

Different letters in the same column indicate significant differences in Duncan's test (p-value $\leq 0.05$ ).

range of 94 to $96 \%$ over the survival rates of the control plantlet (70\%). In addition, the growth parameters such as fresh weight, height and leaf area of strawberry plantlets in the LED lighting system were higher than those of plantlets from the control treatment (Table 3; Figure 9). After approximately 10 weeks of vegetative growth, strawberry plantlets derived from different lighting systems (FL, LED tube, LP and WPT-LP system) started the flowering process and fruit started to form after one to two weeks (Figure 9).

Previous studies have demonstrated that LEDs promoted or induced in vitro and ex vitro plant growth and development (Nhut et al., 2003). The effects of LEDs in plants growth and development were very clear, although, the influence of electromagnetic fields to plant growth was limited. However, there has been a controversy about the effect of electromagnetic fields on plant physiology. Belyavskaya (2004) found that weak electromagnetic fields inhibited plant growth and decreased cell division. Ramezani Vishki et al. (2012) demonstrated that electromagnetic fields enhanced seed germination and root elongation in Satureja Bachtiarica, but restrained shoot length, leaf area, fresh weight and dry weight of explants. In another study, Dao-Liang et al. (2009) found that the electromagnetic field could increase the sprout numbers of Plum (Prunus maritima). However, there was unclear explanation about the effect of electromagnetic field on plant physiology, especially with in vitro culture process. In our study, electromagnetic field was used in a low frequency, at $120 \mathrm{kHz}$, and likely did not cause any change in explant physiology. Wireless power technology has been widely used in mobile devices and for
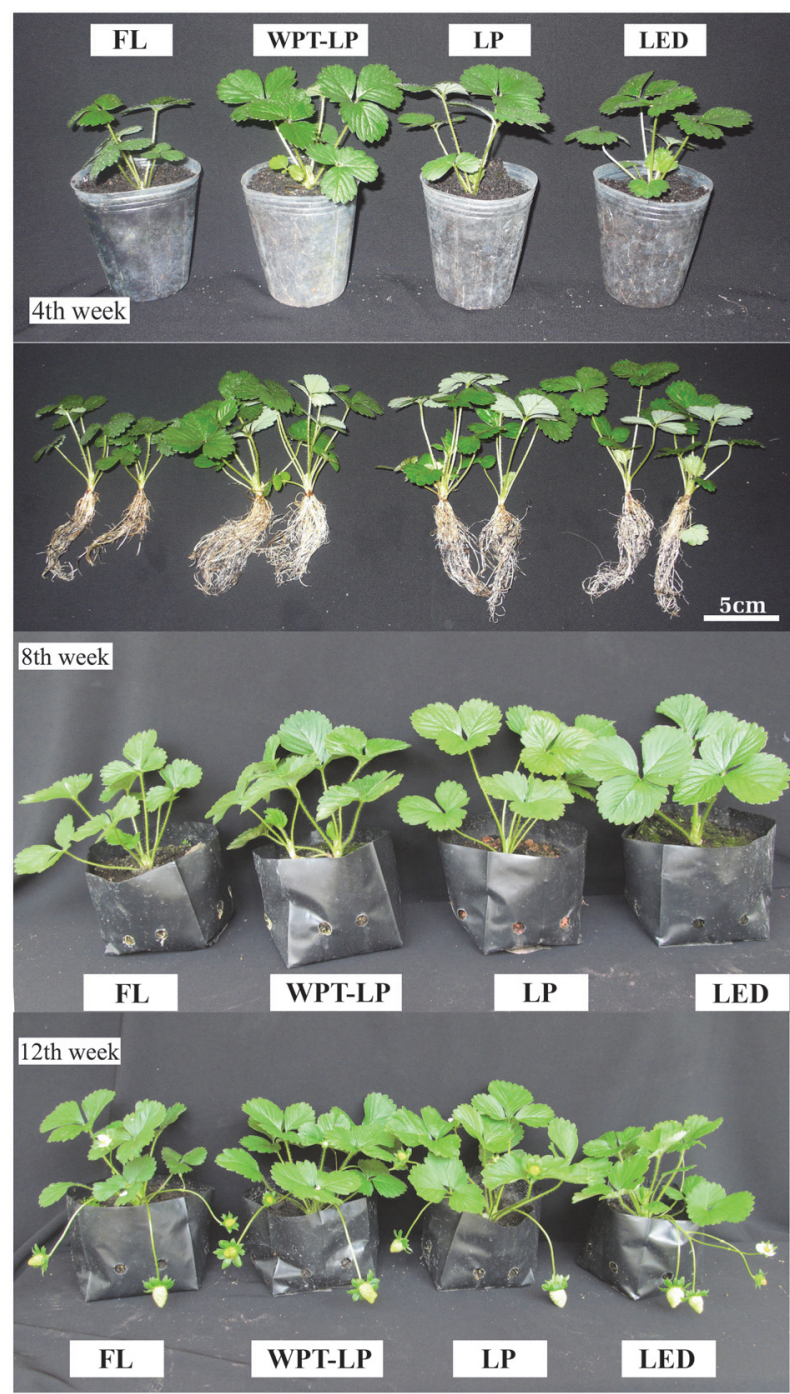

Figure 9 - A comparison of subsequent growth of in vitro strawberry plantlets under different lighting systems (FL; LED tube; LP system; WPT-LP system) after transferring to soil for $4,8,12$ weeks.

the first time ever, in this study, it has been applied to in vitro plant culture tissue. This was a primary research study on the impact of LEDs and wireless power transfer 
system in micro-propagation. Therefore, further studies on interactions between the electromagnetic field, LEDs and the physiology of in vitro plantlets would be important.

In this study, a wireless power transfer combined with LED lighting system was developed. The optimal growth and development of chrysanthemum and strawberry plantlets in WPT-LP is either equal to or better than in LP under LED or FL. Unlike the conventional lighting system, high space utilization was increased 2 times per the same culture area in WPT-LP system. It could be considered as the first attempt to study the application of wireless power transfer system in micro-propagation with some advantages. These studies would provide us with an opportunity to investigate the effects of the combination of light and electromagnetic fields on plant growth and development. With further improvement and experiments to be conducted, we expect that WPT-LP system could be very useful in most of tissue culture systems and plantlet productions.

\section{ACKNOWLEDGEMENTS}

This work was supported by the National Foundation for Science and Technology Development (NAFOSTED), Vietnam, under project no 106.16-2012.32 and the TN3/ C09 project under the National Program of Science and Technology for Socio-Economic Development of Tay Nguyen Region, Vietnam.

\section{REFERENCES}

Belyavskaya N.A. Biological effects due to weak magnetic field on plants. Adv Space Res. 2004;34:1566-74.

Bornwaber T., Tantau H.J. Evaluation of LED lighting systems in in vitro cultures. Acta Hortic. 2012;956:555-62.

Bula R.J. et al. Light-emitting diodes as a radiation source for plants. HortScience. 1991;26:203-5.

Chen C. Fluorescent lighting distribution for plant micropropagation. Biosyst Eng. 2005;90:295-306.

Dao-Liang Y. et al. Effect of electromagnetic fields exposure on rapid micro-propagation of beach plum (Prunus maritima). Ecol Eng. 2009;35:597-601.
Duncan D.B. Multiple ranges and multiple F test. Biometrics. 1955;11:1-42.

Gupta S.D., Jatothu B. Fundamentals and application of light-emitting diodes (LEDs) in in vitro plant growth and morphogenesis. Plant Biotechnol Rep. 2013;7:211-20.

Hayashi M. et al. Effect of sideward lighting on the growth of potato plantlets in vitro. Acta Hortic. 1992;319:163-7.

Kim S.J. et al. Effects of LEDs on net photosynthetic rate, growth and leaf stomata of Chrysanthemum plantlets in vitro. Sci Hortic. 2004;101:143-51.

Kitaya Y. et al. Effects of light intensity and lighting direction on the photoautotrophic growth and morphology of potato plantlets in vitro. Sci Hortic. 1995;62:15-24.

Kozai T., Kubota C., Jeong B.R. Environmental control for large-scale production of plants through in vitro techniques. Plant Cell Tiss Org. 1997;51:49-56.

Kurs A. et al. Wireless power transfer via strongly coupled magnetic resonances. Science. 2007;317:83-6.

Lian M.L., Murthy H.N., Paek K.Y. Effect of light-emitting diodes (LEDs) on the in vitro induction and growth of bulblets of Lilium oriental hybrid 'Pesaro'. Sci Hortic. 2002;94:365-70.

Lichtentaler H.K., Wellburn A.R. Determination of total carotenoids, chlorophyll a and b of leaf in different solvents. Biochem Soc Trans. 1985;11:591-592.

Murashige T., Skoog F. A revised medium for rapid growth and bioassays with tobacco tissue culture. Physiol Plant. 1962;15:473-97.

Nhut D.T. et al. Responses of strawberry plantlets cultured in vitro under superbright red and blue light-emitting diodes (LEDs). Plant Cell Tiss Org. 2003;73:43-52.

Okamoto K., Yanagi T., Takita S. Development of plant growth apparatus using blue and red LED as artificial light source. Acta Hortic. 1996;440:111-6.

Olle M., Virsile A. The effects of light emitting diode on greenhouse plant growth and quality. Agric Food Sci. 2013;22:223-34.

Ramezani Vishki F. Study of effects of extremely low frequency electromagnetic radiation on biochemical changes in Satureja bachtiarica L. Inter J Sci Technol. 2012;1:77-82.

Taiz L., Zeiger E. Plant physiology. New York: Benjamin/ Cummings Publishing Co, 2002. 560p.

Planta Daninha, Viçosa-MG, v. 34, n. 4, p. 617-630, 2016 
Tanaka M., Norikane A., Wantanabe T. Cold cathode

fluorescent lamps (CCFL): Revolution light source for plant micropropagation. Biotechnol Biotechnol Equip. 2009;23:1497-503.
Tanaka M. et al. In vitro growth of Cymbidium plantlets cultured under superbright red and blue light-emitting diodes. J Hortic Sci Biotechnol. 1998;73:39-44. 